\title{
CORRESPONDENCE
}

\section{Ludwig Guttmann's Memorandum: a review on the surgical aspects of spinal cord injuries written in 1944 for the Nerve Injury Committee of the Medical Research Council: with notes and commentary}

Spinal Cord Series and Cases (2017) 3, 17047; doi:10.1038/ scsandc.2017.47; published online 10 August 2017

\section{INTRODUCTION}

During the Second World War, George Riddoch, chairman of the Nerve Injuries committee of the Medical Research Council (MRC), asked Ludwig Guttmann to carry out a review of the surgical aspects of spinal cord injuries (Figure 1). The resulting memorandum, written prior to the opening of the spinal unit at Stoke Mandeville Hospital in February 1944, was thought lost until it was unexpectedly found among a bundle of George Riddoch's papers. ${ }^{1}$ These recently (2017) came into my possession owing to Jill Blau, widow of Nat Blau (1928-2010), a neurologist at Queen Square. This newly discovered document provides a unique insight into the development of the speciality and reveals Guttmann's debt to his predecessors. This debt to forefathers was aptly described by Isaac Newton in a letter to Robert Hooke in 1676 when he declared: 'If I have seen further it is by standing on the shoulder of giants'. In view of (Sir) Ludwig Guttmann's seminal contribution to the treatment of spinal injuries, this memorandum is published in full with a commentary that draws on the author's long professional association with Ludwig Guttmann, which started in 1956, and his work over many years at Stoke Mandeville Hospital.

Born in Silesia in 1899, Ludwig Guttmann worked as a medical orderly at the accident hospital for coal miners in Konigshütte where Wagner had treated spinal injury patients 20 years previously. After the First World War, he trained as a doctor and qualified in 1923. He worked in Breslau under Otfrid Foerster who had a major influence on his future approach and philosophy towards spinal injury treatment. Foerster, who was a master in rehabilitation and the first neurosurgeon in Europe, was described as a doctor who could make the blind see and the lame walk. ${ }^{2}$ Guttmann received a thorough training in neurology, neurosurgery and in rehabilitation of peripheral nerve injuries as Foerster treated over 4000 such cases. ${ }^{3}$ When the Nazis came to power, Guttmann lost his position as Foerster's assistant and worked for 5 years at the Jewish hospital in Breslau. In 1939, he escaped to England but could not practice clinical medicine for 5 years as his qualification was not recognised. He worked in the Department of Surgery under Professor Hugh Cairns, carrying out research on peripheral nerve injuries but was extremely frustrated and considered leaving to enter general practice. His unique knowledge of rehabilitation of peripheral nerve injuries was recognised and he gave a lecture on the subject in the distinguished company of Geoffrey Jefferson at the Royal Society of Medicine, which was published in $1941 .^{3}$ Guttmann was curiously reticent about this paper, although his ideas on peripheral nerve rehabilitation were subsequently incorporated into spinal cord rehabilitation.

Historical context

As Hitler's aggression spread across Europe, a resumption of hostilities was inevitable. Unlike the First World War, when casualties had all been servicemen, many civilian casualties were anticipated because of bombing. In 1939, Riddoch was appointed consultant neurologist to the army with the rank of Brigadier. He was chairman of the MRC committee on peripheral nerve injury, with responsibility for setting up spinal injury units. On the eve of the Second World War, only three British doctors had any experience of treating spinal injury cases; George Riddoch who was Resident Medical Officer in charge of a spinal unit at the Empire Hospital during the First World War, and Gordon Holmes and Henry Head who had both treated cases during the First World War. The Staff were not appropriately trained; physiotherapy was not yet fully established so exercise was not being used to rehabilitate patients. Occupational therapy was in its infancy as a profession with an ill-defined role; 'any activity, mental or physical... hastening recovery from disease or injury'. ${ }^{4}$

A series of spinal units under the direction of Frank Holdsworth, an orthopaedic surgeon, and the neurosurgeons Geoffrey Jefferson and Norman Dott were opened on Riddoch's recommendation to treat spinal injury cases; these units were not properly staffed and the patients lingered in appalling conditions. ${ }^{5}$ At 63 and 78, respectively, Holmes and Head were too old to take an active part in treating casualties with spinal injuries. In contrast, Riddoch was 51 and worked tremendously hard, not only setting up the units but visiting them, advising the consultants, treating the patients and offering to carry out the neurology at the spinal unit at Stoke Mandeville as there was no neurologist. Riddoch invited Ludwig Guttmann to write a review of the surgical aspects of spinal injuries for the nerve injuries committee of the MRC because of his extensive experiences in the rehabilitation of peripheral nerve injuries. This memorandum is written from the Department of surgery in Oxford where Guttmann, then aged 40, was working for Hugh Cairns until 1944. The background to this document is curious. No other copy could be found in the Guttmann archives at the Wellcome Library, in the Stoke Mandeville Hospital Library archives or in the Public Record Office. A comparison with his own handwriting confirms that Riddoch extensively annotated Guttmann's draft document, mainly to correct the English and the use of medical terminology but also where Riddoch's own work is discussed on pages 10 and 11. Unfortunately, these notes are in pencil and difficult to decipher.

This memorandum is valuable on three counts: firstly, it delineates the contemporaneous level of understanding of the treatment of spinal injuries. Secondly, it reveals Ludwig Guttmann's early thoughts and opinions on how best to treat such patients and, finally, it marks the beginning of the comprehensive 
NERVE INJURIES COMMITTEE

of the

Hedical Res e a r c h c o uncil

A REVIEW ON THE SURGICAL ASPECTS OF SPINAL CORD INJURIES

by Ludwig Guttwann

(Froin the Departinent of Surgery, University of Oxford)

\section{INTRODUCPION}

In this collective review an attempt has been made to present as briefly as possible the various concepts of the treatment of spinal cord injuries current among workers in foreign countries. The works of American, French and especially Gerinan experts on this subject during and since the last war are quoted.

The review is nainly concerned with the problens of orthow paedic and operative treatinent, though eaphasis has also boon loid on first-aid wanagement and pre- end post-operative care. other methods of treatment such as exercise and occupational therapy have not been included but a detailed description can be found in. the writer's review of methods of rehabilitation following lesions of the nervous systein (1941).

\section{Statistics - Classification}

Haumann (1926) found in 843 cases of closed vertebral injuries 6\% (23\%) spinal cord lesions. The highest record of spinal cord lesions $34(43 \%)$ was found in injuries to the cervical spine, whereas injurjes to the thoracic spine showed 49 (42\%) and those to the luabar spine 43(91\%) spinal cord lesions. The spinal cord lesion was a complete transverse lesion in 50\%. Schmeiden (1930) recorded in his statistics of 3014 fractures of the spine 2105 cases, $e_{\circ} . g_{0}, 33 \%$ mith partial or complete lesions of the spinal cord. llarburg (1336) found in 50,000 casualtjes 100 cases with vertebral injuries, $50 \%$ of which were spinal cord lesions.

Statistics on war injuries of the spine with spinal cord lesion have been published by llarburg and Ranzi (1918) with 155 cases (145 gunsiot injuries), Cassirer (1921) with 184 cases (174 gunshot injuries) and Foerster (1929) with 395 cases (279 gunshot injuries). According to statistics of gunshot injuries in various G whand counties and wars (G. Holmes, Graf and hildebrand, Otis) gunshot Wwat injuries of the spinal cord are lost frequent in the thoracic ctit region, Retained bullet wounds are classified as extradural, intradural and intrafiedullary. Stab wounds of the spinal cord occui in the majority of cases in the upper thoracic and lower cervical regions. In Wagner's and Stolper's collection (1898) of 86 cases the upper thoracic region was injured in. $52 \%$, in Petrén's (1910), of 93 cases, 54\% were in the upper thoracic region.

Besjdes gunshot and stab wounds the causes of war injuries to the spinal cord include explosions, falls fron a height, "run over" accidents, direct blows upon the back by horse shoes and other objects, being buried in trenches, and blows froil falling wasonry. In peace tiale Morrison and Flawson (1935) have tabulated the causes of compression fractures of the spine as direct falls $69 \%$,

\section{Over/}

Figure 1. Ludwig Guttmann's Memorandum: a review on the surgical aspects of spinal cord injuries written in 1944 for the Nerve Injury Committee of the Medical Research Council. 
motor car and troin accidents $16 \%$, direct trama $9 \%$, forceful sitting $5 \%$, heavy flexion in lifting $1 \%$. In a recent American statistic Con wel1. (1939) reported that 8,000 of 13,000 fractures of the spine in the U.S.A. in 1937 were caused by motor car accidents.

\section{Mtechanisin of Spinal Cord Lesions}

During and since the last war the complicated nechanism of spinal cord injuries has been repeatedly discussed in many countries. Only a fow points can be mentioned in this review. A blunt or penetrating Iorce, striking the vertebral colukin, can produce a great variety of deformities of the spine, e.go, forward or lateral islocation of one or lore vertebre, fracture-dislocation of any part of the arch of the vertebrae, etc. Similariy, either transitory or persistent narrowing of the spinal canal way result. The cord lesions (resulting frou all these derorinties) inay vary froil slight concussion, causing only a transient functional block, to a partiel or coiplete transverse division. Further, according to Foerster and others, in wany cases lesions may occur at various levels of the spinal cord abore and below the level of the primary lesion, due to the transinission of the force of the blow to the colurn of the cerebrospinal fluid and to the spinal roots. This mechanisid is also thought to explain those cases where the spinal cord lesions are nore severe than one would expect froa the degree of Injury to the vertebral coluin; probably the force striking the vertebral colum causes only a tronsitory deformity of the shape of the spinal canal, the bones returning to their noral position without gross injury; but the momentary deforition of the spinal canal inay have been sufficient to produce a profound and persistent injury to the spinal cord. The dissociated cord lesions which can often be found in such cases have been attributed to a contrecoup nechanisin coused by the lich of cadaption of the spinat cord to the sudien wovenentis of the verteoral colum at the time of the ianging force. A transmission effect in transverse direction cau sed by the impact of a bullet has also been assumed in traction lesions after gunshot injuries which have involved a rib or shoulder girdle (Reinhurdt, Heinecke, Leva, Waus and Krueger, Foerster).

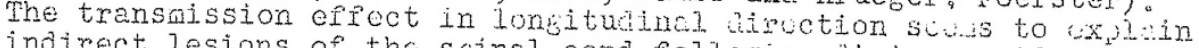
indirect lesions of the spinal cord following diving accidonts or due to forceful sitting.

A lesion of the spinal cord due to gunshot injury can be associated with a fracture of the spine far away frow the initial trama due to suaden forceful contracture of the back muscles. Foerster (1928) has described such a cuse in which a gunshot injury of the Brd. thoracic vertebra was associated with a unilateral fracture of the transverse processes of the 3ra. end 4th. lumbar vertebrae. He assumed that tis fracture was caused by the acute strong uniluteral contracture of the erector spina sibilar cases have oeen recorded by Schlagwitz (1920) and ieuss and Kuefer (1921). Recently this opinion has been confirned by the experience with the metrazol shock therapy in psychosis. These experiences have eliminated ang doubt that a surden strong contracand Fitzpatrick (1939) and cause a froturce ol the spine. Bennett and Fitzpatrick (1939) and Bemett and Has Sa (1939) have reported X-reys showed one or 1 of cases treated by this hethod, the

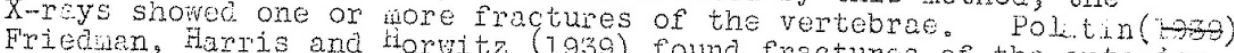
parts of the bodies of The bone lesion was found in the wajority of cases between the 4 th. and Ioth. thoracic vertebrae. In this connection former experience of fractures of the vertebrae occurring during tetanus infection

Figure 1. Continued. 
First $A 1 d$

The correct first aid treatuent of person with a voptebral, cord injury day actucily save his life or at lusst provent his becowing a hopeless cripile. Siecial trainlag should therefore bo included in 211 first ald courses and is of particular value in dealing with injured persons in coclines cind aif raid rictins. The following weasures for the transport of an injured person suspected of a vertebral and spinsl cord lesion aro recomended:

1. In order to prevent further dislocation of the frectured verbetree the patient should never be noved by a single person. He should be irept fist on his beck until three or four persons are available to lift hij with the grectost care.

2. The patient should be transported on a rigid stretcher, or, if this is not available, on a board. Bandages round the paralysed legs and feet should not be too tight. Hard ojjects should be renoved frow his back pockets and places with prominent bones should be bolstered imediately, janticularly if transport to the next casualty clearing station takes a long time.

3. If the dorsal, lumbar or secral regions of the suine are injured, and a doctor is not readily available to correct the position of the patient, he sholild hive a cushion or other improvised support urider the siiall of his back and should have his arrs folded above or bohind his heid. Soue authors reconmend turning the patient fuce downwards. H, however, the nature of the injury very often cannot be diagrosed by first-aid parties, it seems better policy not to undertake such alterations of position without medical supervision.

4. Patients with suspected cervical lesions should be transported with slight traction on the head and a slight hyperextension of the cervical spine in order to roduce the possibility of cord involvenent. "The heed should never be bent forward.

5. The patient should be covered with blankets to preserve the body heat and dininisin general shock.

6. The saile general care nust be taken in transfering the

injured fro:a the stretcher to a bed, $X$-ray or operating taie. Ihis again has to be done by three persons, The roscuers should give the physician in the casualty clesing station a full account of the accident and thoir observations of the state of the patient imedately after it. It is especialy iuportant in deciding on treatient to know whethes the jutient was comiletely paralysed directly after the accident.

\section{Ireatuent of the Genera 1 Shock}

It is beyond the scope of this review to describe all the details of treatiuent of general shock frow which wany jatients suffer imediately after a spinal. cord injury. One point, however, needs special considerstion: tho aplication of heat. It is interesting to note that in traviatj.c sinit cord lesions sweating in the supralesionary areas of ta. body moc! by hoat is a good objective sign that the pationt has ovicone the first traunetic shock (personal observation). It mus, howovex, always be borno in wind, perticularly after triumatic EESions of the midile and upor pert of the thoracic region, and of the cervical region, that the therioregulatory iathways in we simal cord below the level of the lesion are interruptod, aud that in any cases the function of a variable extent of the sinal a r abore the level of the lesion is abolished by the $s_{j}$ ind shoc. Whis weurs that the greater part of the body surfece is wable to oliainate heat by sweating Heat should therefore not be used indiscílinatert

Figure 1. Continued. 
after sinal-cord injury; it should only be applied under medical supervision and hot water bottles should never be allowed against the infralesionary anaesthetic areas of the body. The writer has repeatedly seen burns in such cases in surgical departinents. In three cases the burns produced by hot water bottles were particularly extensive in the ankle and knee regions. In one case a radiant heat cradle had caused a noderate burn in the lower abdominal region.

\section{Treatment of Closed Injuries to the spine Without and With Spinal Cord Involvement.}

The present trend in the treatment of fractures and dislocation of the spine without sinal cord danage is definitely conservative. on the continent in recent years two opposed methods have been dogmatically recommended by their instigators: (1) Boehler's method of correct reduction and fixation followed by immediate and systematic exercise. This method is based on the ideas of Davis (1929) and Watson-Jones (1931), also Alfred Taylor of New York (ca 1928): (2) Magnus's inethod, based on Kocher's principles, which rejects inanipulative reduction, except in particularly badly deformed verteorae and in spine injuries with spinal cord involvement. He tries to get the best functional results by rest coibined with immediate active exercise, It is beyond the scope of this review to discuss the details of these nethods. Both authors and their followers claim excellent functional end results but no agreenent has so far been reached. (Felsenreich (1933), Schleipen (1935), Boehler (1935), Karitzky (1937), Leser and Hayer

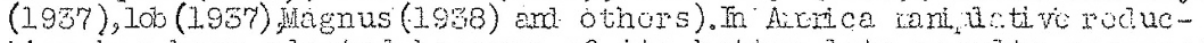
tion has been adopted bocause of its better late results compred with older methods. Eikenbary (1928) estinates that only $2 \%$ of petients had less than $10 \%$ disability under older nethods. Harbugh and Haggard (1930) found in 97 consecutive ceses of fractured dorso-lubar spine an average of $45 \%$ disability (rated after 31 months) after treatient by rest, imobilisation and physical therapy; and 50\% disability (rated after 50 inonths) after treatment by operative stabilisation (Albee grafts, Hibbs fusion).

A great number of authors in various countries belicive that the keynote of the treatient in closed spine injuries with spinal cord involvement is also conservatisin, and that lominectomy has only an exceptional place in these injuries. Stookey's arguments against laminectomy are: (1) better reduction can be accomilished by non-operative methods, (2) laminectomy removes much of the bone structure invaluable for stability of the vertebral column, (3) opening the dura may allow the cord to extrude and cause rupture of intact spinal cord substance, thus converting a partial lesion into a complete one. Earlier authors (Kocher, Thorburn, WagnerStolper, de Quervain, Nest-Kolb) had already empasised that operative intervention, particularly early operation, represents a serious danger to life and to the danaged spinal cord.

Although sowe detalls of Stookey's arguments can certainly not be genercilised, manipulation and reduction of fractures with a spinal cord lesion is believed by inany authors to offer the best prospect for recovery. Boehler, for instance, claims that paralysis due only to pressure of the dislocated sine, blood clot or oedeme, will disapear in a few days. He saw paralysed patients regain cajacity for norial a bevent within a week, and sensation returned ci few hours after reduction. Unfortunately, he has never given exact details about the clinical signs in such cases. In fractures of the cervical spine with cord involveinent he rejects continuous traction by GIisson's sling because of the restlessness of the patient lying in the sling which in his opinion may increase oedena and haeworrhage. He found Glisson's sling successful only in partial dislocation. In cervical injuries reduction is carried

Figure 1. Continued. 
out under local anaesthesia and in recent ceses is usualiy obtained with a traction of $15-25 \mathrm{~kg}$. after $1-3$ minutes. As soon as reduction has been achieved the traction is reduced to $5-6 \mathrm{~kg}$. If a lateral X-ray shows a good position of the spine the plaster cast is immediately applied. Boehler rejects, however, plaster cast in the thoracic and lumbar region because of the danger of sore by pressure.

Boehler's optimistic view about the value of manipulative reduction in fractures with spinal cord lesions has not been universally accepted. Wagnus (1938) round this method unsatisfactory in his own cases and other authors are still using extension in Glisson's sling in cervical lesions. Froil ily own experience I, too, cannot confirm Boehler's pessimisw with regard to Glisson's sling in cervical injuries. Munro and Irwin (1939) found that manipulation is poorly tolerated in cervical injuries and is even worse than laminectomy. They agree with Crutchfield (1937) in giving trial traction varying from four to thirty-six hours; if there is no improvement laminectomy should be considered. This brings us to the discussion of the indication for operative treatment in spine injuries with cord lesions. There is graat difference of $\sigma_{\text {ininion }}$ a.ong neurolugists, surguns and opthopaedists as to the indications fur o, aretive intervention and In articular es to the bist date for the suration. The groatest difficulty is that the turit "early $o_{1}$ arotion is difforently inter roted by diffurent athors and has still. to be dofinod. Yot to-day there is universal agrew ent on one

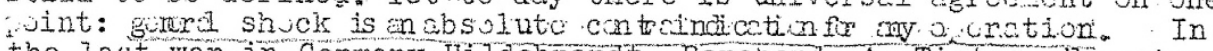
the last war in Germany, Hildebrandt, Borchard, A. Tietze, Förster, and others recomended early operation, $i . e$ operation in the first days after injury as soon as the patient's general condition permitted. In their view all clinical signs were unreliable for the differentiation between anatomical transverse lesions and merely compression lesions of the cord due to impinged bone, haemorrhage, etc. They recomended operation as early as possible to remove any compression from the cord. Foerster stressed the point that early operation may even prevent development of a posttraumatic oedema. This radical standpoint has been abandoned by the majority of surgeons since the introduction of the Queckenstedt 1925 test (CCleman, 1-93\%) and of myelography (Peiper, (1926), Heymann instance, in a case with a complete transverse syndrome no manometric block is found early operation can presumably be rejected. Dowman (1930) has emphasised that the wanometric test should be repeated as the block found immediately after injury may only be transitory. I can confirm this view. In 1936 a patient showed a complete cauda syndrome due to fracture-dislocation of the 2 nd. and 3rd. Iumbar vertebrae following a skiing accident. The manorietric test about 14 days after the injury showed, besides a yllowish stained cerebrosinal fluid a complete block. The patient refused operation, yet in the following period she improved siontaneously although the recovery was not complete (perisistent interruption of the 5th. Iumbar - 5th. sacral roots in the left side at the tirne of discharge from hospital about 8 inonths after injury). Two lumbar punctures at later dates showed only an
incomplete manometric block.

The diagnostic value of a complete and persistent manometric block is also limited in those cases in which a compession of the spinal cord - say by dislocated bone -.- is associated with an irreversible lesion of the spinal cord itself.

No definite conclusion can be arawn from the laterature about the value of ryyelography in acute spinal injuries with and without spinal cord involvement. Peiper (1926) could recognise by myelography rupture of the dura in one case. This was verified at

Oront

Figure 1. Continued. 
$-6-$

operation. Heyann (1989) stated that an incoplete block of the injected lijiodol indicates a groater chance of a successful imediate pieration than a comlete and perwanent lijodol sto.

Sumarising the various views of authors with great surgical ex $x_{1}$ erience in $s_{x}$ inal cord injuries the following stateinent may be nede:-

\section{Early Ojeration.}

operation in the first days after an injury, moviding the patient's genersi condition is satisfactory, nay be indicatad in the following circuistances:-

(a) Direct pressure on the cord by dislocitea bone or bone fragacnts shom by $\mathrm{x}-\mathrm{rcy}$. Cases showing an incolilete trensversal syndrome require ininediate operation the wore urgently to prevent further daiage to the cord by the bone fraguent. 0yerative interference should especially be considered where mani ulative reduction hos been unsuccessful. It way be imentioned that even Boehlei recowinends operation as early as the first day in cases of fracture-dislocation of the lumbar sine without fracture of the articular processes if hyperextension has not succeeded.

(b) Coniste or incomiete transverset syndroue of the cond or caude equina with conlete manometric or 1 indodol block in ceses without any ajpreciable fracture or dislocation of the sine. Blood-stained cerebro-spinal fluid without ilanowetric block does not justify imediate operation.

(c) Paralysis develo,ing hours or days after the accident indicating progressive haemorrhage or oedene. Foerster in mrticular has dram attention to the danger of jrogressive waralysis in longitudinal direction following cervical sine injuries. With regard to the jarticularly dishal prognosis of conservative treatment in such cases early ojerative interferenco ary bucone imerative as the only chance to save the life of the pationt. In Foerster's Case 192 following fracture of the 4 th. and 5 th. cervical vertebrae, describod in his book (1929), a progressive transvarse syndrome develojed within two days after accident with early resuratory paralysis. At operation the cord was found (1) to be very oedenatous particularly at the level of the 3rd. cervical seginent. The most prowinent jert of the cord corresjonding to the left antero-lateral tract was incised and detritus with serous fluid was renoved, leaving behind a sall cavity in the cord. A few hours after operation the wotor function of the right aria and leg, and on the next day also of the left arin, returned; the wotor function of the left leg recovered a reek later. Thereafter the motor function recovered comletely. only residual sign was a therianalgesia of the right side of the body below $\mathrm{C}_{4}$. one and a half years later there was only isolated anaesthesia for cold with paradoxical werd sensation in that area. Foerster ewijasised that in such cases luibar juncture as recoimended by Borchardt, and even a decoinipessive larinectouy without incision of the cord way not prevent the jrogness of the oedera. The sane operative mocedure is recowimden in cases in which the wogressive symptous are caused by troulatic haedatayelie. A mere decompressive lauinectoing is useless as shown in Foerster's Case 185 .

A larget subdural haenotowa, although certainly rare as the consequence of a silinal injury, can also be res,onsible for the development of such a jrogressive transverse syndrowe in the first days after injury and represents also an indication for imediate pperation. An interesting examile of this grou is Foersteris Case 182 (1929):

Figure 1. Continued. 
A patient developed severe pain of girdle type in the middethoracic region several. hours after a fall down the steps. The pain gradualiy increased in a downward direction. On the following day there was severe sain in both legs and in the coccyx. On the third day there was marked paresis in both legs with bladder disturbances; jain continued, esjecially in the 5 th. and 6th. thoracic derwatomes. On the fourth day there was comilete transverse syndrome below the 4 th. thoracic deriatome. Pain was absent below that level, but was present above it in the upper thoracic dermatomes. No operation was possible in this case because of additional jneuionia. At autopsy an interiaral haematone was found comressing the cord severely at the level of the 4 th. thoracic segment and extending downwards to the cauda equina. The orisin of chis haemorrhage was a ruptured aneurysm. of the radicular artery of the left $3 r d$. thoracic root. The vertebral colum was intact.

Early ojeration may be of particular inijortance in cases in which a large subdural haeidatora involves the roots of the cauda equina. Even a more conservative surgeon like Elsberg (1940) recomends early operation. in such a case. Besides the fact that early removal of a big haematoma in this region may have an immediate beneficial effect in injroving the bladder function, early operation may also prevent the dense adhesions which usually result from the organisation of such a haematoma. Moreover, suture of divided roots is certainly easier at an early operation. It inust, however, again be ein hasised that slight or woderate discolouration of the cerebro-spinal fluid does not justify an early operation.

A similar develo juent of symptoins occurs in a progressive epidural haenorrhage following spinal injuries. Usually in such cases the irritative syuptoms (pein, nuscle spasm) are predominant and, unless there is an aditionel prinary cord lesion, the sinal syintons are in general slight or negligible. However, de Quervain (1908) and Foerster (1928) have jointed out that an extraaural haenatoila can joduce a transverse lesion of the cord,

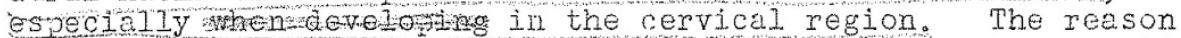
is that in that region of the sulne the venous plexusisare parti-

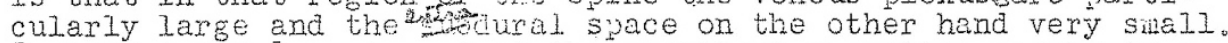
In $1935 \mathrm{~A} . J . M c L e a n$ cocorlbed the excellent operative result in a case of Practure-dislocation of the 1Ith. dopsal vertebra with Gidural hagnatoina: 12 hours after the accident the 16-year old patient showed, besides nared tenderness in the 11th. and 12th. thorscic deriutoules, only analgesia of the 1st. and 2nd. lumbar derwatomes. The entire saddlo area as well as the tendon reflexes were normel. The symitons gradually increased and 30 hours after the accident there was practically complete paraplegia with absent reflexes and sensory disturbances, wore narked in all lumbar than in sacral regions. At operation 48 hours after the accident the islocation of the vertebra was confirwed and partially corrected and an epidural haenatoma compessing the cord was removed. A thick posterior plaster shell was iloulded to the watient before he ras renoved from the table. The clinical signs receded within a period of 9 weeks. In tie $14 t$. week he was fitted with a Taylor brace and began to sit wint. During the 20th. week he began to walk with i! stjck. At the 39 th. week the residual syndroise ras an incomilete Brow-Sequard comilex.

(d) Irritation of sinal roots. There is no doubt that severe and persistent irritation of sina roots efter sinal injuries caused by iminging bone framents, etc., may be an indication for early operation. This conditicn, however, is rom rere. Elsberg(1940) has seen only one caso of incoinlete s,int lobloz in the last 20 years in which the severe root pain was sufficient indication for early surgical interference. Othor cases have been described by Foerster.

Over 1

Figure 1. Continued. 
$-8-$

2. Late Oiveration.

There are no great differences in opinion about the beneficial effect of operative treatient in later jeriods after sininal cord injuries and both the Queckenstedt test and inyelography can greatly facilitate the decision jor operative interference. The indications for late operation can be sumarised as follows:-

(a) Comiression of s,inal cord and silial roots by deformities of the spine. Exiperienceu authors agree on the beneficial effect of laninectoily in cases of sinal cowression due to parked angulation, callus fornation, rolapsed intervertebral disc, and other deforities of the silne. Foerster (1929) stressed the point that a remarkabje functional rocovery way follow the rewoval of such a coriression even when carried out long whise after the

injury. As exanjos of this grou the following cases, described by this author, may bo ilentioned:

Case 174. Fracture of the 8th. and 9th. thoracic vertebrae. Complete transverse lesion below the llth. thoracic dematone. Hotor paralysis at first flaccid, later systic. Flexion reflex

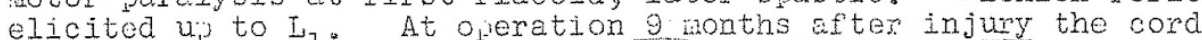
wes found strongiy coupessod at the level of the lith. thoracic seginents by the dislocated bone. There mas iwediate good julsation of the cord after decoupression. After operation hyjerextension was ajilea. Gradual, marked inrovenent of notor and sensory function of the lower linbs. Voluntary action of the bladaer.

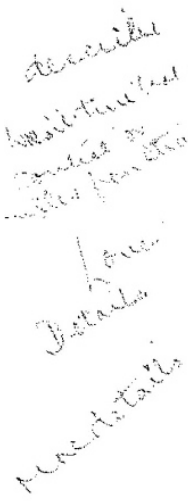

Case 175. Fracture of the 3rd. Iumber vertebra with complete cauda equina syndrone below $I_{g}$. Severe cystoryelitis, sestic teujeratures, decubitus at the scicruin. Decoupression of the severely comisessed cauda equine 8 wonths after injury. Very remarkable i rrovement of uotor, sensory and bladder function. Two and three-quarter years after operation the patient was able to walk forl - 2 hours.

Case 151. Fracture of the 6th. and 7th. cervical and of the Ist. thoracic vertebrae. Operation 2 years after injury. because of increase of sinal syiptous due to callus foriation. After operation gradual inroveruent. Two years after operation even the intrinsic juscles showed definite signs of rocovery. only the abductor pollicis brevis rewained jaralysed, (At operation the lst. thoracic root was found severed, and a suture was not possible).

(b) Meningopathia. A progressive compression of the sipinal cord by chronic jechym or lejtomeningitis has been rejeatediy described. According to de Quervain post-traumatic pachyieningitis results from organisol eji-and subdural hasintoinas or bone fraginents.

E.Is berg and Foerster found this condition jarticularly in traumatic lesions of the cauda equina. Foerster used to replace the excised thickened dure by a graft taken froi the fascia lata. of gnenter ractical itortance is the lejto teningitis serosa seu "arachnitis chronica jogressiva cystica adhaesiva" (o, penheirn, Krause, Foerster, warburg, Cassirer, Souques, Gauduchau, Bouthier, and others). This condition has been described either as additional noxis to the initial spinal cord or root lesions or as ar quite inde jendent one in cases without any or only sinute initiel sjinal syit,to fis, following injury. As characteristic signs for the diagnosis of this condition are described: (1) stagnation or increase of sulnal sym, tois after initial insovenent; (2) fluctuation of sijina? symptons in extent and intensity; (3) increased pressure of the cerebro-s,inal fluid with and without serological changes: (4) comilete or incomilete manoinetric block; (5) cowjlete or (rrequently) artial li jiodol block. Although in general ieningopathy wore usualiy develojs after a longer interval it nay occasionally be found very marked only a fortnight after injury.

Figure 1. Continued. 
Foerster, elthough describing several cases with good operative results ew wasised that, in the bajority of cases with chronic neningitis serosa, the improvenent of the sinind symtons was not very uarked, and he ossuined that in these cases a jost-traumatic vasojathic jrocess with progressive thrombosis of the sinal cord vessels, as described by harburg and others, wes resionsiblo for the irreversible cord lesion. At operation the findings are sowetimes iost iniressive. The sijnel cord is not only conpressed by one or severel cysts, but it is also disjlaced and even twisted by the traction of the fibrous canesions ( ${ }_{1}$ ersonal observation)。

(c) Haenatomyelia. Elsberg (1940) recominded laminectomy and incision of the cord in cases of heevitouyelia in which marked syciston wersist or in which nany months aftex injury en increase

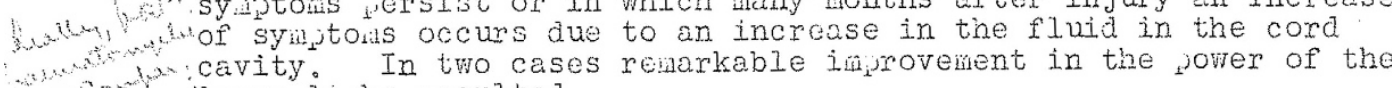

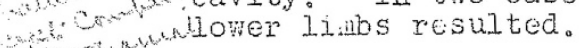

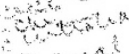

ar. (d) Osteomyelitis. Osteomyelitis following closed injuries of the sijine is very rare. Foerster has described only two cases.

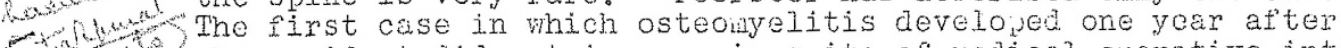
$y$, the accident aid not impove in spite of radical overative intorvention, and the vatient died of meningitis. In the second case osteoungelitis occurred about 6 months after the accident during
an angina infection. This case healed by conservative treatient twal an ang na infection. This case healed by

(e) Irritative syndrones. Since the last war persistent severe pain by irritation of sinal roots following sinal injury has becoule an inortant incication for surgical interference. Ir some cases jain may be im,roved and even rolieved by ropeated aravertebral novocain or alcohol injections. In cases of losttraunatic irritation of lumbar and sacral roots removal of a rolapsed intervertebral disc or of the thickened ligaientum flavun has been cerried out successfully in recent years in various countries. There is hardly any doubt that after the war this ojeration nay lay a inost injortant part in the treatient of post-trauinatic "sciatica". A great number of cases with josttraunatic irritation of sjinal roots has been treated with section. of posterior roots. Indeed, this o, eration has iroved very successful, iarticularly if at least three neighbouring roots are divided. In cases, however, in which the pain cannot be attributed to individual roots and involves larger areas of the body the surgical inethod of choice is bilateral clordotoin. As far as Foerster's and ny own experience wth this wethod are concerned unilateral cordotony has proved useless in the majority of cases. It was the jractice in Foerster's clinic to carry out root section and in particular cordotoily under local anaesthesia. It may be e. 1 hasised, however, that the indication for dordotony in irritation synaroues following sinal injuries is very rare.

(f) Palliative surgical treatinent for sjastic and flaccid jaralysis. In a certain number of cases with inconjlete transverse lesions following spinal cord injury rehabilitation is prevented or delayed by the persistent spasticity of the lower limbs which renders locomotion imossible desite good notor wower. The nethods recomended for reducing siasticity are: (1) section of josterior roots as introduced by Foerster; (2) partial resection of jerineral nerve trunks combined mith lastics on tendons and Huscles as described by Stofiel, Gocht, Foerster, and others. In recent years section of posterior roots for reducine laderate spasticity has rarely been carried out. It should be reserved for extreme flexion spasm in coiplete transverse lesions where it gives the patient great relief, and greatly racilitates his

Figure 1. Continued. 
nursing. In flaccid jaralysis due to anterior root or anterior horn lesions jlastics on muscles and nerve anastouses have been carried out and can be useful in accelerating rehabilitation after spinal cord injuries.

Treatwont after eunshot injuries to the s,inal cord.

Surgical treatiment of gunshot injuries of the spinel cord is based on principles similar to those described in the treatment of closed injuries. According to statistics of previous wars gunshot injuries of the sinal cord occur most frequently in the
thoracic region. They are, however, also described in all the other parts of the spinal cord and cauda equina causing the various complete, inconplete and dissociated syndromes. woreover, the varjability of the transmission effect in transverse and Icngitudinal directionscaused by the speed, power and course of the bullet is irmense. In addition, a number of gunshot injuries of the spinal cord are associated with injuries to the brain and other i.jortant organs or with a secondary fracture of the spine due to wuscle contraction or fall froin a height. It must be remembered that in the last war gunshot injuries of the cervical or even the upper thoracic region were described associa"ted with cerebral symptoms such as unconsciousness lasting froui a few minutes to 36 hours and jersistent paralysis of the 5 th. 7th., 8th., 10th., lith., and izth. eepebral nerves (Rosenfeld, Lewa, Foerster, and others). Some authors (Cassirer, Foerster) found aphasia in sowe cases. Last but not least, the danger of infection is naturally greater after gunshot injuries than after closed injuries of the spinal cord. The surgical treatrient has therefore to take into account a greater number of factors. In soine cases the immediate rewoval of a bullet retained in the spinal cord has to be postponed because of the associated vital injury to internal. organs or severe general shock. All these factors make it even more difficult to outline absolute rules for indications for early operation in gunshot injuries than it is in closed sijinal injuries. Where are, indeed, only few occasions in neuro-surgery in which an individualising procedure could be wore essential than in gunshot injuries of the spinal cord, and any dogmatisis has in the past proved unsatisfactory. The experiences of Foerster and others, for instance, have shown that the removal of an intradural or intramedullary bullet or fragment as early as 24 hours after injury has neither prevented the steady progress of sinal symptoms nor the infection in later periods following injury. Thus surgical interference in gunshot injuries within the first hours or days may be indicated only in exceptional cases.

on the other hand, it must be kept in mind that a bullet or other foreign body in the spinal canal or its neighbourhood is a focus of infection which should be removed as soon as possible. Woreover, especially in gunshot injuries of the cauda equina, any foreign body leads as a rule to immense fibrous reaction: and dense adhesions between foreign bodies and roots may resul, thus rendering a late operation, say $6-8$ weeks after injury, most difficult, eren far a skilied neuro-surgeon. Furthermore, wandering of retained intradurat bulfets, as described by

Heinecke, Saenger, Simmonds, Auvray, and others, may increase the danger of a secondary injury to the spinal cord. All in all, considering the various views based of the experiences during and since the last war one coines to the conclusion that bullets or other foreign bodies carried into the spinal canal should be removed at the earliest possible date.

\section{Stab Wounds.}

Injuries of the spinal cord jroduced by knives, bayonets, and other sharp instruments are rare. Cassirer (1921) reported one case among 184 other injuries; Foerster (1929) 6 among 365

Figure 1. Continued. 
cases. As rentioned before the ujer thoracic and lower cervical regions are involved in the majority of cases. The upper thoracic region was injured in 52\% of Wagner's and stolper's (1898) 86 cases, and in $54 \%$ of Petrén's (1910) 93 cases. Foerster has described stab wounds between 4 th. -5 th, 5 th, -6 th. and 8 th. -9 th. thoracic vertebrae. In numerous cases the knife blade was broken off and $a$ piece remained stuck in the spinal canal or in the bone. As a rule the lesion of the sijinal cord is imnediate. $r_{e t}$ there are a few exceptional cases in which the retained knife blade was undiscovered for many years and was first found when spinal syaptoms develo,ed many years later (Peugnioz, terthes, van Gehuchten). In general a transverse lesion follows immediatel on the injury, but if the cord is not completely divided, the symtous sulside wore or less rapidy and the residual syndrome is that of a partial cord lesion. In a case ae Foerster's clinic (1932) following stab injury between the 3rd. and 4th. thoracic vertebrae there was at first a nearly comilete transverse lesion below Th, with suaring only of the right sino-thalanic tract. In the left analgesic sart of the body below the level of the lesion nocice tive-stimuli (pin-prick, julling hairs) could, howerer, not be differentiated. After reinoval of the broken blade, about 14 days after injury, there was a gradual inarked improvement of the spinal symptoias. The resiaual spastic paresis

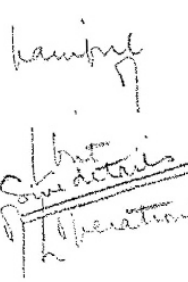
of the lower limbs, especially the left, was further improved by tendon plastics. Surgical treatment has also jroved successful in cases described by other authors. According to the literature the danger of weningitis following stab wounds of the sijinal cord is apparenty swall.

\section{Care of the bladder and intestines.}

It is universally recognised that the paralysis of the bladder and bowels following spinal cnrd injury dewands the wost careful attention frow the outset. Neglect of the appropriate neasures or delay in ado jing them may postpone or render useless the most skilful surgical treatment. Yet in practice it is still not fully apreciated that both the medical and nursing staff in not fully apreciated that both the medical and nursing staff in
casualty clearing stations, etc., must be familiar with the jrinciples and iuethods of the treatinent of the various kinds of bladder dysenction. Horeover, it should be rewembered that in some cases of injury to the vertebral colum the spinal lesion of the bladder may also be associated with a lesion of the peripheral nervous pathways of this organ due to jrevertebral haematona, etc.

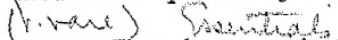
The key spinal cord injury are: - (1) Drainage of the urine must be con(2) Heticulous care and cleanliness inust be observed whatever (2) Heticulous care and cleanliness inust be observed whatever no method so far devised can completely prevent wadader infection, but in many cases the infection can be prevented from spreading to the ridneys. No definite conclusions can so far be drawn frow the literature whether suprapubic cystostony, with $1937)$ is the ilethod of choice for bladder drainage. On the continent many clinicians still prefer the use of an indwelling catheter, coibined with irrigation with $3-4 \%$ boric acid solution or hivanol solution $(3: 1000)$ once or twice a day to prevent accuinulation of Trosphates at the base of the bladder and on the inner surface of the tube. Opinions regarding the frequency of change of the catheter vary from 2 days to several weeks. It is not aw of the catheter vary from 2 lays to several weeks it is not
$=-4$ generally apreciated that, whatever inethod inay be used, catheteri-
wation and irrigation should only be done by the medical officer wan to sation and irrigation should only be done by the medical officer to (3) Restriction of fluid by gouth in the early stages has been Wha recommended (Stinchfield, 1940), but the general ojinion is that rate the patient should be encouraged to drink freely and that the urine

Figure 1. Continued. 
$-12-$

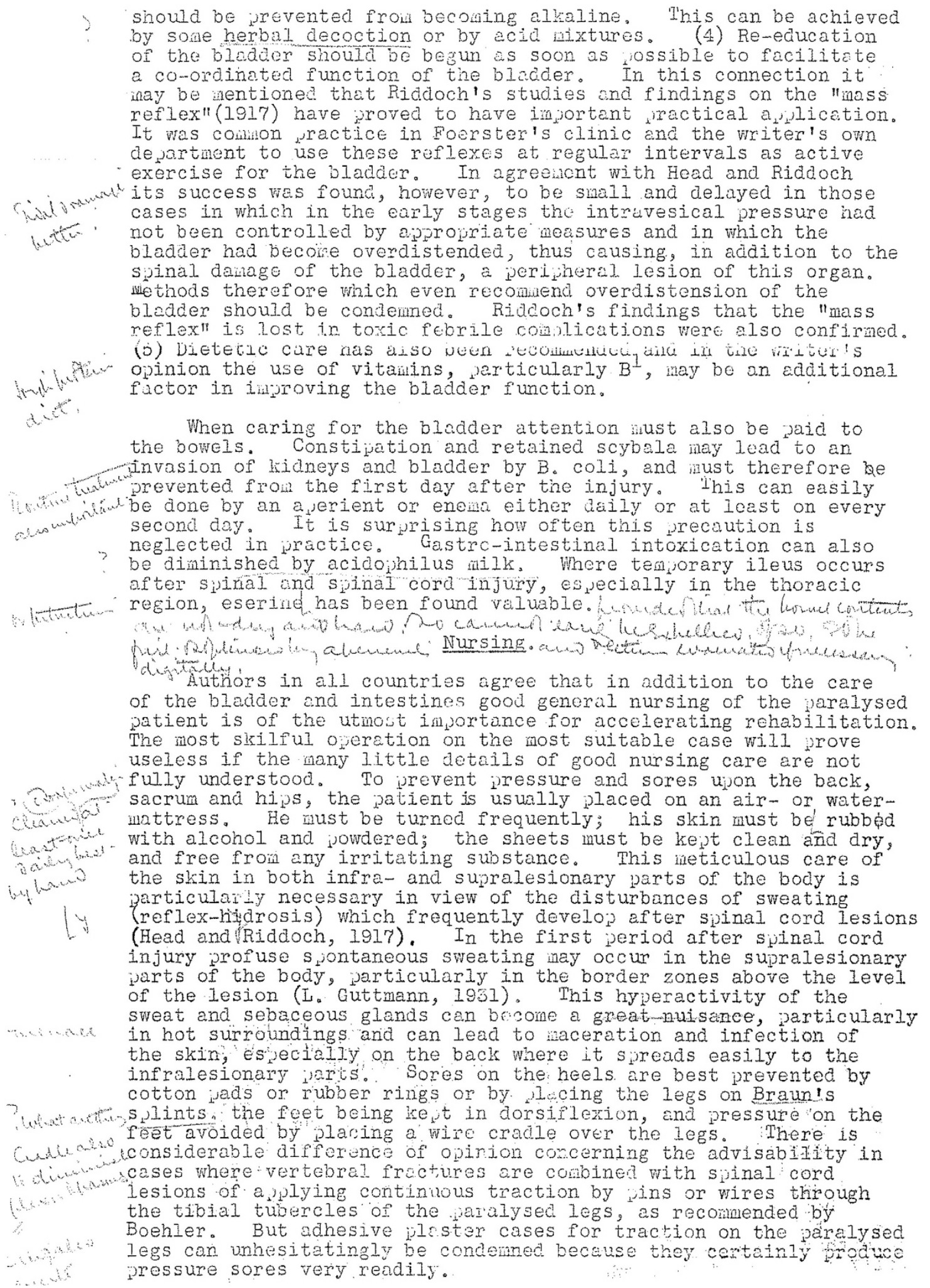

Figure 1. Continued. 
The practice in Foerster:s olinio was to place the feet in dors ifleyion while avoiding rigid fixation and traction of the lower limbs. Pessive movements and massage of the paralysed limbs were apolied as early as possible following injury, and, as soon the less reained any active movement, a systematic action exercisestreatment was begun. The details of this are described in the writer's reviem on the methods of rehabilitation following lesions of the nervous system (1941).

\section{PEPREMNCES}

Auvray, $\mathrm{M}(1916)$ Bull.koas.Hed., Earis. 76 . 447. Bennett, B.T. and Fitzpatrick,C.P.(1939) J.Amer.med.Ass. 1122240 . Boehler, I. (1935) "The Treatment of Fractudes" J.Wright, Bristol. "1938) Arch.Klin.Chir. 193,644。

Coleman C.C. (1925) J.Amer.med.AsS.85 1.206. Conwell, H.E. (1939) Ibid. $113,4 \overline{90}$ Crutchield. G. (1937) Amer. Surg. 38, 592 Cassirer (1921) z.Neur.70 (quoted by Foerster on page 1805) Davis, AF. (1929) J. Sone Jt. Surg. 11, 133 Dowman, C.E. (1930) Southem med.J. 23, 607. Eikenbary, C. F. (1928) J. Hiner.med.Ass. 91, 1694 Elsburg, C.A. (1940) "Injuries of the skuII, brain and spinal cord" 495. (S.BROCK) Bailiere, Tindall and Cox, London Felsenreich, F.(1933) Aroh.klin.Chir.176,123

Foerster,0 (1929) Die traumatischen Iasionen des Ruckenmarks, auf Grund der Kriegserfahrungen." Handb.Neurol. Frganzungsband, Vol. 2, J.Springer, Beriin.

Friedmann, See Polatin et all. 1939 J.Lner.Hed.Lss.112, 1687

Gutimani, (1930) Hefte zur Unfaliheilkunde, 8, 37 (1931) Z.Neurol. 135, 38

Homsa, 1.R. and Bennew L.E.T(1939) J.mer.Fed.Lss. 112 2244. Haumann, W. (1930) "Die Hirbelbruche und ihre Endergebnisse" F.Enke, Stuttgart.

Farbaugh, R.W. and Haggard, R.E. (1930) Calir.Wegt.Med.32, 325

Harris end Horwitz (1939) J.Lmer.Med.LSs.112, 1687

Head, H. and Riddoch G.(1917) Brain, 40, 188

Feymann (1930) "Die Chirugie", 3778 Firohner-ivordmann

Karitsky (1937) Lroh.Klin.Chir. 190, 669

Leser, A.J. and Mayer, C (1937) Frch.kIin.Chir. I90, 523

Lob (1937) Dtsch.z.Chir. 278, 452-466.

Molean, H.J.(1935) Northw. Hed., Seattle, 34, 84

Hagnu.s, G. (1938) hroh.klin. Chir. 191, 54.

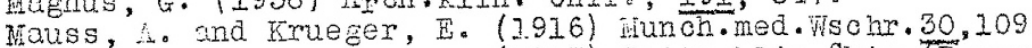

(1917) Beitr.klin.Chir.TBruns.Beitr.) 108,143

Mauss, (1921 Z.Neur. 66 I-58(quoted Foerster P. 3 1723)

Narburg,0 (1936) H andb.Neurol.11,100. Springer, BerIin.

Harburg, 0 and Ranzi, E.(1918) Arch.klin.Chir.111, I

Morrison, Wo is and Flamson, R.J.(1935) Colif. West Ied., 43, 436.

Prunro.A.H.G. and Irwin, G. (1938) Brit.J.Surg.25, 621

Munro D. and Halm,J. (I935) New ingI. J.Med.2TL, 229

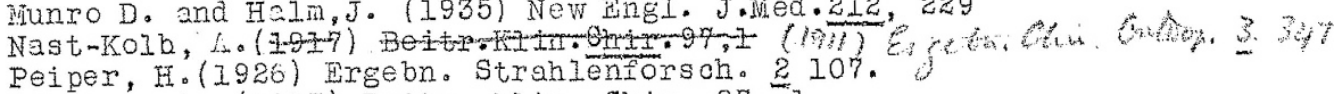

Perthes, i. (1917) Beitr. klin. Chir. 97 1 .

Retren K. (1910) irch. Psych.47, 495.

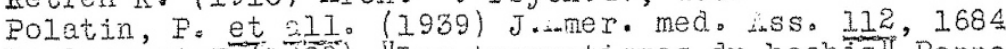

De Quervain Internat. Bruzeiles.

Ranzi, $\mathrm{F}_{\text {。( }}(1918)$ See Harburg and Ranzi (ref.Page 13)

Riddoch, Go (1917) Brain, 40, 264

Schlagwitz (1920 Hed. Klin. E.927 (quoted by Foerster on P.1722)

Schleipen, $\ldots$. (1933) Dtsch.2.Chir. 238, 618

Stinchfield, F.E. (1940) Surg.Cynec.0ostet.70, 378

Stookey, B. (1.937) Ibid. 64407

Wrgner, W, and Stolper, Po (1898) "Die Verletzungen der mirbelsale und des Ruckenmarks."F. Encte. Stuttgart.

ratson Jones, No(I931) Brit。 ned. J. I, 300。

Figure 1. Continued. 
The practice in Foerster"s olinio was to place the feet in dors ffexion while atoiding risid fixation and traction of the lower limbs. Pessive movements and massage of the paralysed limbs were apolied as early as possible following injury, and, as soon as the legs reained any active movement, a systematio actio as the the details of this are described in the writer's revien on the methods of rehabilitation following lesions of the nervous system (1941).

\section{PEBERENCES}

Auvray, M(1916) Bull.Acas.Med. Earis. 76447 .

Bennett, B.T. and Fitzpatrick,C.P. (1939) J.Amer.med.Ass. 1122240 . Boehler, I. (1935) "The Treatment of Fraotuses" J.Wright, Bristol. is (1938) Arch.Klin. Ohir. 193, 644.

Coleman C.C. (1925) J.Amer.med.iss.85 1106. Conwell, $\mathrm{H} . \mathrm{E} \cdot(1939)$ Ibia. $113,4 \overline{90}$ Crutchield. . (1937) Amer.J.Surg. 38, 592

Cassirer (1921) Z.Neur.70 (quoted by Foerster on Page 1805)

Davis, AF. (1929) J. Sone J.t. Surg. 11, 133

Dowman, C.E. (1930) Southem med.J. 23, 607.

Fikenbáry, C. F. (1928) J. Amer.med.iss. 91, 1694

Eisburg, C.A. (1940) "Injuries of the skuli, brain and spinal cord" 495. (S.BROCK) Bailliere, Tindall and Cox, London

Felsenreich, F.(1933) Aroh.klin.Chir.176,123

Foerster, 0 (1929) "Die traumatischen Iasionen des Ruckenmarks, auf Grund der Iriegserfahrungen. "Handb.Neurol. Erganzungsband, Vol. 2, J.Springer, Berlin.

Friedmann, See Polatin et all. $1939 \mathrm{~J}$. Lner.jed.Lss.112, 1687

Gutmann, I (1930) Hefte zur Unfaliheilkunde, 8,37 II (1931) Z.Neurol. 135,38

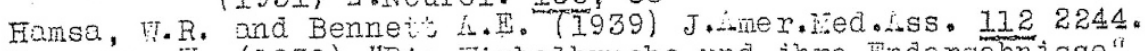

Haumann, W. (1930) "Die Mirbelbruche und inre Endergebnisse" F.Enke, Stuttgart.

Harbaugh, R.W. and Haggard, R.E. (1930) Calis.Wegt.iled.32, 325

Harris end Horwitz (1939) J.4mer.Med.LSs.112, 1687

Head, H. and Riddoch G.(1917) Brain, 40, 188

Feymann (1930) "Die Chirusie", 3778 Hirohner-Nordmann

Karitsky (1937) Lroh.KIin.Chir. 190, 669

Leser, A.J. and Mayer, C (1937) Frch.kIin.Chir. I90, 523

Lob (ig37) Dtsch.z.Chir. 278, 452-466.

Molean, L.J.(1935) Northw. Hed., Seattle, 34, 84

magnus, G. (1938) Lroh.klin. Chir. 191, 547.

Maus, L. and Trueger, I. (1.916) Tinch.med.Wschr.30,109

(1917) Beitr.klin.Chir.TBruns.Beitr.) 108,143

Mauss, (1921 Z.Neur. 66 I.58 (quoted Foerster P. 3 1723)

Narburg, 0 (1936) H nab.Neurol.11,100. Springer, Berlin.

Harburg, 0 and Ranzi, E.(1918) Arch.klin.Chir.111, I

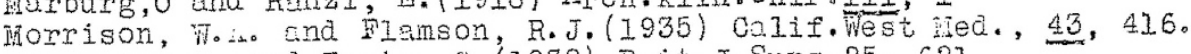

Irunro.A.H.G. and Irwin, G. (1938) Brit.J.Surg.25, 621

Munro D. and Halm,J. (1935) New ingI. J.Med.2IZ, 229

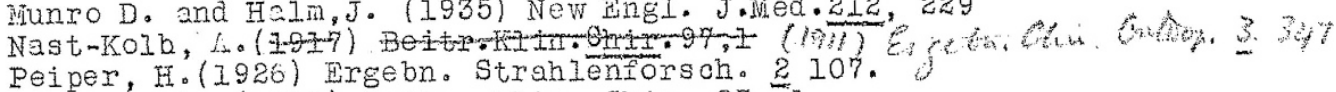

Perthes, i. (1917) Beitr. klin. Chir. 97.1.

Retren K. (1910) irch. Psych.47, 495.

Polatin, $\mathrm{F}$. et $1 \mathrm{I}_{0}$ (1939) J.mmer.med.4ss. 112, 1684

De Quervaint (108) "Ises tranatismes du haohis" Rapport congr. Internat. Bruzelles.

Ranzi, $\mathrm{F}$ 。(1918) See Wrburg and Rinzi (ref.Page 13)

Riddoch, Go (1917) Briin, 40, 264

Schlagwitz (1920 Hed. Klin. E.927 (quoted by Foerster on P.1722)

Schleipen, $:$. (1933) Dtsch.2.Chir. 238, 618

Stinchifid, F.E.(1940) Surg.Cynec.0ostet.70,378

Stookey, B. (1.937) Ibid. 64 407

Wrgner, , and Stolper, P. (1898) "Die Verletzuneen der mirbelsule und des Ruckenmarks."F. Enc.e. Stutteart.

Fatson Jones, No(I931) Brit。 ned. J. I, 300。

Figure 1. Continued. 
treatment of spinal injuries. These notes are not meant to be an exhaustive criticism armed with hindsight of the memorandum. It is the memorandum that is of prime importance as it marks the start of the comprehensive treatment of spinal injuries.

\section{OVERVIEW}

\section{General remarks}

Despite the fact that he had not treated patients for 5 years while he was carrying out research and for the previous 7 years he had been working at the Jewish Hospital, away from Foerster's specialised unit, his observations are acute, practical and well thought out. Guttmann was erudite and scholarly in his research, and he provides a very detailed and thorough analysis of the literature, especially the German contribution. This was a formidable task in those days before the Internet, unlike today when a literature search is available at the press of a button. His knowledge was not just theoretical, derived from study of the literature; he clearly had treated patients in Foerster's department and could evaluate the different forms of treatment in light of his own experience.

He repeatedly emphasises how the doctor should be in total charge of the patient, a cornerstone of his treatment. He does not discuss exercise in detail or occupational therapy as these have been addressed in a previous article on peripheral nerve injury (1941), but Guttmann uses the same methods to rehabilitate spinal injury patients as applied to peripheral nerve injury patients. $^{3}$

\section{Detailed remarks}

Mechanism of spinal cord lesion. He knew about fractures in tetanus infections in metrazol shock therapy due to the strong contraction of the erector spinal muscles and multiple fractures at different levels. He describes the mechanics of injury and the dissociation of cord injury from the site of the injury, the contrecoup mechanism seen in gunshot wounds of the spinal cord with the fracture far away from the initial trauma.
First aid. With regard to the administration of first aid, his management of the patient cannot be bettered, stressing the need for a doctor to supervise the lifting and transfer of the patient and obtaining an accurate history from the outset.

Treatment of closed injuries of the spine. He reviews the literature with a careful analysis of the arguments for and against surgical intervention and fixation, and the whole passage can be read with profit today. He discusses two different forms of treatment, manipulative reduction followed by fixation as described by Boehler as opposed to Magnus whose method based on Kocher's work that rejected manipulative reduction. He does not come to any conclusion but, fascinatingly, he adopted Magnus's method, called it postural reduction, as his standard method of treatment, rejecting all forms of surgery on the basis that it destabilised the spine and could lead to deformity. He discusses the dangers of laminectomy, in that it destabilises the spine, and later in his own practice he became vehemently opposed to this, based on his own experience in the management of these cases and how general shock is contra- indication to any operation. This has been underlined by Riddoch in the document, suggesting that it is of prime importance. He devotes eight pages to the treatment of the fracture in spinal injuries. He discusses critically the indications for surgery and, contrary to his later views, he favours early operation where there is direct pressure on the cord, the rapid development of progressive paralysis or the presence of a haematoma. He would later abandon these views in favour of more conservative management of the fracture. ${ }^{4}$ He discusses palliative surgical treatment for spastic and flaccid paralysis where he discusses section of the posterior roots introduced by Foerster. He subsequently rejected this form of treatment and carried out an alcohol block.

Management of the bladder. In the First World War, the majority of patients died rapidly of urinary infection spreading to the kidneys. Thomson-Walker found that out of 339 patients with spinal cord injuries between 1915 and 1919, 47 died from urinary tract infection 8-10 weeks following injury. ${ }^{6}$ Guttmann discusses

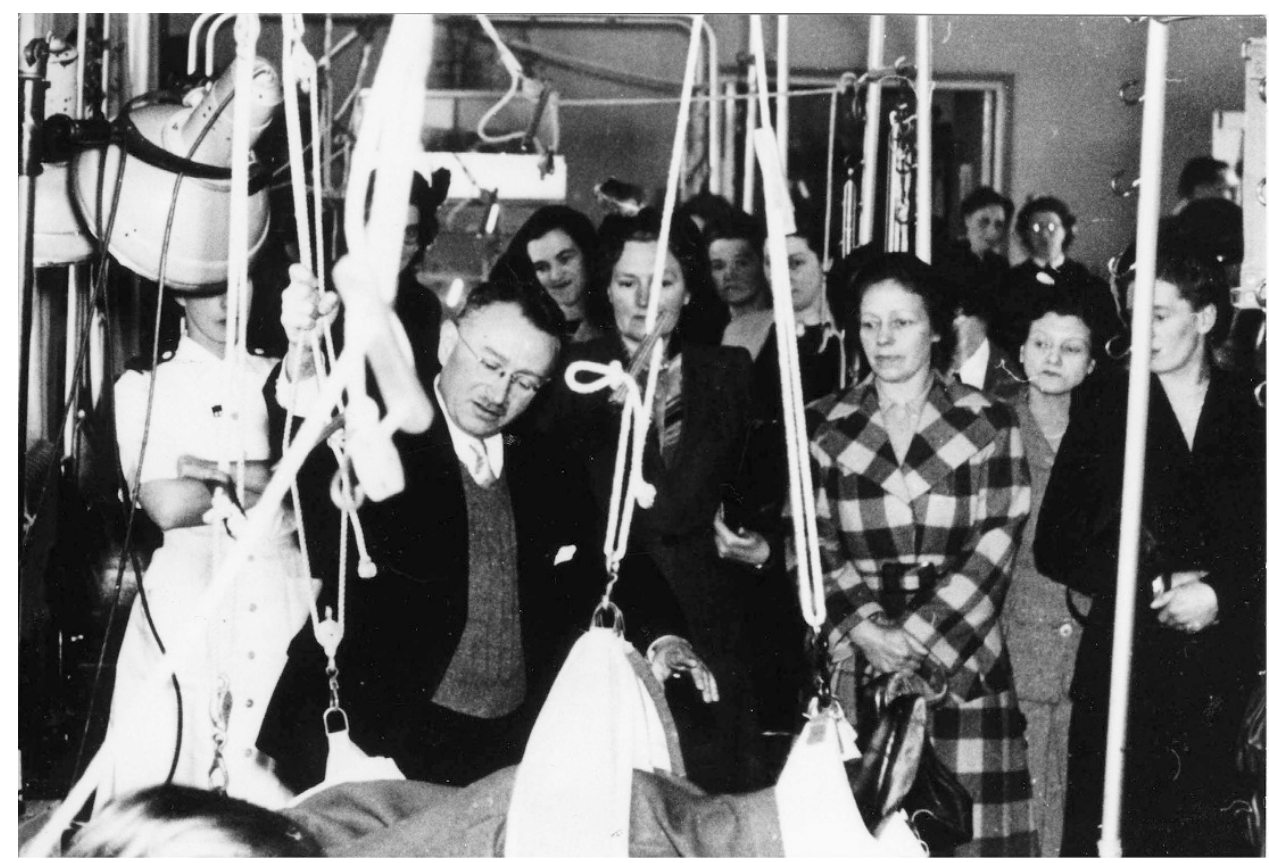

Figure 2. Ludwig Guttmann teaching in the physiotherapy department at Stoke Mandeville Hospital. Personal photograph taken from History of the Treatment of Spinal Injuries, 2003, JR Silver, Chapter 3, p.86. Reproduced by kind permission of Springer Science+Business Media BV. 
the methods of draining the bladder. This section is widely annotated by Riddoch who emphasises the danger of overdistension of the bladder. Guttmann only mentions the danger of infection spreading to the kidneys; he does not address the mortality. He discusses whether the methods of drainage should be continuous or whether there should be washouts. He does not fascinatingly discuss the method of intermittent catheterisation as practiced by Wilhelm Wagner, William Thorburn and John Hulke, and which he subsequently introduced at Stoke Mandeville Hospital. $^{7}$ He does stress, however, that the overall care of the bladder must be the responsibility of the doctor and not the nursing staff.

Pressure sores. Despite the overwhelming danger of pressure sores, he only mentions these in a few lines. He does not discuss how pressure sores can penetrate the skin, involve the bone and cause death.

General care of the patient. He devotes a passage to the position of the patient to prevent contractures and shows his profound knowledge of physiotherapy and nursing. He was light years ahead of anything in the UK, and he taught the students of the School of Masseurs at Stoke Mandeville Hospital how to treat patients (Figure 2). His teaching and precepts served as an inspiration to physiotherapists throughout the UK and beyond.

Thermoregulation. He stresses the impaired sweating caused by paralysis.

\section{CONCLUSION}

Ludwig Guttmann had direct experience of spinal cord injuries, which he drew upon to treat the patients. He stressed that a doctor should be in charge of all aspects of treatment. Despite the fact that it was a surgical paper, he dealt with pressure sores and the care of the bladder. Clearly at this stage his mind was open and various ideas that he had from his own experiences and review of the literature were not fixed into dogma. The cornerstone of his treatment, which he maintained throughout his professional career, was the holistic care of the patient that all aspects of treatment must be integrated as a whole.
'The most skilful operation on the most suitable case will prove useless if the many little details of good nursing care are not fully understood'.

\section{COMPETING INTERESTS}

The authors declare no conflict of interest.

\section{ACKNOWLEDGEMENTS}

I would like to thank Jill Blau for bringing this memorandum to my attention.

\section{PUBLISHER'S NOTE}

Springer Nature remains neutral with regard to jurisdictional claims in published maps and institutional affiliations.

John R Silver

Emeritus Consultant Stoke Mandeville Hospital, Buckinghamshire, UK Correspondence: JR Silver (jrussellsilver@btconnect.com)

\section{REFERENCES}

1 Goodman S. Spirit of Stoke Mandeville the Story of Sir Ludwig Guttmann. William Collins Sons and Co: London, 1986, pp 93.

2 Haymaker W, Schiller F. The Founders of Neurology, 2nd edn., Charles C Thomas: Springfield, IL, USA, 1970, pp 555.

3 Guttmann L. Discussion on rehabilitation after injuries to the central nervous system. Proc $R$ Soc Med 1941; 35: 305-308.

4 Guttmann L. Spinal Cord Injury Comprehensive Management and Research. Blackwell Scientific Publications: Oxford, London, Edinburgh, Melbourne, 1973, pp 104.

5 Dick TBS. Rehabilitation in Chronic Traumatic Paraplegia- A clinical study. MD thesis, Victoria University, Manchester, 1949

6 Thomson Walker JW. The treatment of the bladder in spinal injuries in Wars. Proc $R$ Soc Med 1937; 30(Part II): 1233-1240.

7 Silver JR. Management of the bladder in traumatic injuries of the spinal cord during the First World War and its implications for the current practice of urology. BJUI Int 2011: 108: 493-500. 